
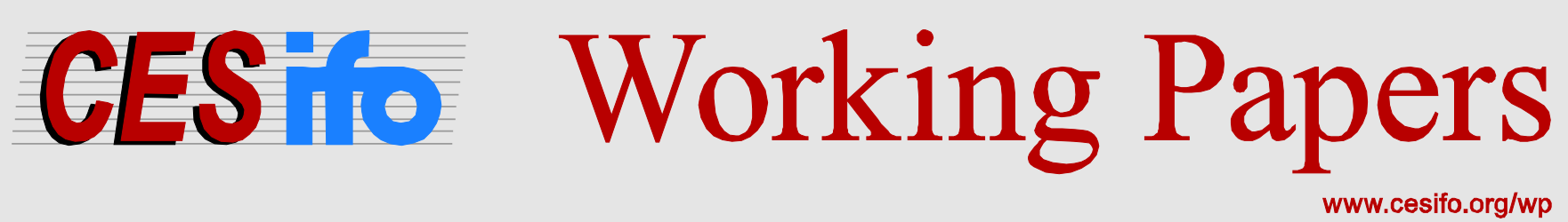

\title{
Land Grabbing and Ethnic Conflict
}

\author{
Tim Krieger \\ Daniel Meierrieks
}

CESIFO WORKING PAPER NO. 6006

CATEgORy 2: Public CHOICE

JULY 2016

An electronic version of the paper may be downloaded

- from the SSRN website:

- from the RePEc website:

- from the CESifo website: wWw.SSRN.com

Www.RePEc.org

www.CESifo-group.org/wp 


\title{
Land Grabbing and Ethnic Conflict
}

\begin{abstract}
We study the effect of large-scale land acquisitions on the risk of ethnic tensions for a sample of 133 countries for the 2000-2012 period. Running a series of fractional response models, we find that more land grabbing activity is associated with a higher risk of ethnic tensions, indicating that the negative effects of land deals outweigh their potential benefits. In addition to that, we also show that democratic institutions may moderate the relationship between land deals and ethnic tensions. That is, non-democratic countries face a substantially higher risk of ethnic tensions as the level of large-scale land acquisitions increases; by contrast, strongly democratic countries tend to see lower ethnic tension risk.
\end{abstract}

JEL-Codes: F210, F630, O130, O430, Q150.

Keywords: large-scale land acquisitions, land grabbing, conflict, ethnic tensions, democratic accountability, weak institutions.

$\begin{array}{cc}\text { Tim Krieger } & \text { Daniel Meierrieks } \\ \text { University of Freiburg } & \text { University of Freiburg } \\ \text { Department of Economics } & \text { Department of Economics } \\ \text { Wilfried Guth Chair of Constitutional } & \text { Wilfried Guth Chair of Constitutional } \\ \text { Political Economy and Competition Policy } & \text { Political Economy and Competition Policy } \\ \text { Wilhelmstr. 1b } & \text { Wilhelmstr.1b } \\ \text { Germany }-79085 \text { Freiburg } & \text { Germany-79085 Freiburg } \\ \text { tim.krieger@vwl.uni-freiburg.de } & \text { daniel.meierrieks@vwl.uni-freiburg.de }\end{array}$

July 8, 2016 


\section{Introduction}

Over the last decade, large-scale land acquisitions (LSLA) have become the center of a heated political and academic debate (cf., e.g., Diergarten and Krieger, 2015). ${ }^{1}$ On the one hand, proponents of such land deals emphasize its advantages, e.g., in the form of socio-economic opportunities for local economic development when foreign investors utilize arable land more efficiently (e.g., Deininger and Byerlee, 2011). On the other hand, critical voices stress the ill effects of land deals on local economies (e.g., unemployment) and the environment (e.g., Cotula, 2011); here, it is argued that neither local governments nor international investors typically consider the effects those deals have on local populations and smallholders. ${ }^{2}$

In this contribution we want to study the effect of LSLA on ethnic tensions. Ethnic tensions are associated with broader political instability and, consequently, reduced economic performance (Easterly and Levine, 1997; Alesina et al., 2003; Alesina and La Ferrara, 2005; Blimes, 2006). Many countries — especially in the Global South—that have increasingly become the target of LSLA are simultaneously plagued by high levels of ethnic fractionalization and, subsequently, ethnic tensions; what is more, many of these ethnic conflicts are also contests over land as a scarce commodity (e.g., Williams, 1994; Bob, 2010). LSLA activity may affect the likelihood of these conflicts. That is, depending on whether LSLA have predominantly positive (e.g., by stimulating economic activity) or negative (e.g., by leading to forced migration and environmental damage) effects, LSLA may ultimately reduce or promote the risk of ethnic tensions.

We study the relationship between LSLA and ethnic tensions for a sample of 133 countries for the 2000-2012 period. Running a series of fractional response models, we find that more LSLA activity is associated with a higher risk of ethnic tensions. What is more, we also show that this relationship is moderated by a country's level of democratic accountability. While strongly democratic countries tend to see somewhat lower ethnic tension risk as LSLA activity increases,

\footnotetext{
${ }^{1}$ Following the definition of the Land Matrix (Land Matrix Global Observatory, 2016), our main data source used in this contribution, LSLA may be defined as intended, concluded or failed attempts to acquire land through purchase, lease or concession. A more detailed definition is provided in Section 3.

${ }^{2}$ From an economist's perspective, this argument boils down to a problem of negative external effects that - by definition - are ignored by the investors. Hence, the immediate policy implication would be to establish appropriate property rights (see also Diergarten and Krieger, 2015).
} 
countries with no democratic accountability (i.e., autocracies) face a substantially higher ethnic tensions risk with higher levels of LSLA. This latter finding is in line with other findings (e.g., Bujko et al., forthcoming) that stress the importance of (weak) institutions in shaping LSLA and their eventual socio-economic effects.

Our paper is structured as follows. In section 2, we lay out the theoretical arguments underlying our analysis. Section 3 provides information on the data and empirical methodology, while section 4 presents our main findings. Section 5 concludes.

\section{Theoretical Considerations}

LSLA activity may trigger ethnic grievances through several ways. For one, ethnic conflicts are often contests over land as a scarce commodity or over the benefits this land yields (e.g., Williams, 1994; Bob, 2010). If LSLA activity aggravates land scarcity or produces benefits of interest for various ethnic groups, ethnic conflict may intensify. For another, specific ethnic groups are often concentrated in specific areas. These ethnic groups share close economic and cultural bonds with the land they inhabit, e.g., because they live on agriculture or because important places of worship or memorial sites are located there. If LSLA activity is likewise concentrated in specific areas, it may especially affect those ethnic groups living in these areas. Depending on whether LSLA is_primarily_beneficial or disadvantageous, this may also influence the potential for ethnic conflict.

In general, LSLA activity may (i) promote ethnic tensions (when its impact is primarily disadvantageous) or instead (ii) reduce the risk of ethnic tensions (when its effect is mostly beneficial). This is because in the former case LSLA reduces the opportunity costs of conflict (e.g., by inducing unemployment), while in the latter case it raises the opportunity costs associated with ethnic tensions (e.g., by fostering economic growth). ${ }^{3}$ Potentially, (iii) local institutional conditions are also important, determining whether the beneficial or harmful effects of LSLA on ethnic conflict prevail, consistent with the notion that institutions matter to LSLA activity (e.g., Bujko et al., forthcoming). Figure 1 summarizes our theoretical considerations regarding on effect of LSLA on ethnic tensions. Below, we discuss the various transmission channels from LSLA activity to ethnic conflict in more detail.

\footnotetext{
3 The idea that opportunity costs strongly influence the likelihood of conflict is a basic assumption of many economic models of conflict (e.g., Collier and Hoeffler, 1998; Esteban and Ray, 2011).
} 


\section{-Figure 1 here-}

How LSLA may increase ethnic conflict risk. One strand of the literature emphasizes the negative consequences of LSLA on local development. Generally speaking, these consequences may include:

- Increased local competition for "traditional", small-scale farmers from large-scale, capital-intensive agribusiness. This competition may cause small-scale farmers to give up their land, resulting in increased unemployment and more poverty (e.g., Robertson and Pinstrup-Andersen, 2010; Davis et al., 2014).

- Increased economic insecurity. For one, when large-scale farms resulting from LSLA primarily produce crops for export markets, this may increase local food insecurity (Robertson and Pinstrup-Andersen, 2010). For another, a focus on specific “cash crops” for exports may make a country's agricultural sector more vulnerable to global price instability, which may further amplify local economic insecurity. ${ }^{4}$

- Forced migration and expulsions. While farmers may give up (i.e., sell) their land voluntarily due to increased competition, there is also the-very real-possibility that predatory interests (e.g., local elites, aggressive foreign investors) use some form of force (e.g., pressure from private militias or a corrupt local police) to remove “traditional” land-owners involuntarily (e.g., Feldman and Geisler, 2012). Negative corollaries of these expulsions are the loss of traditional livelihoods and of indigenous farming knowledge as well as the creation of —-however crude-land-rights markets that disregard traditional land rights and of a large pool of cheap labor from the impoverished displaced (e.g., Robertson and Pinstrup-Andersen, 2010; Feldman and Geisler, 2012).

- Environmental effects. More intensive agricultural production as well as resource extraction (e.g., mining) that result from LSLA activity may result in, e.g., soil degradation, desertification and pollution (e.g., Robertson and Pinstrup-Andersen,

\footnotetext{
${ }^{4}$ This insecurity is further increased when investments in and production shifts toward cash crops cause a Dutch Disease-like effect (e.g., Corden and Neary, 1982). Increasing inflows of foreign investments and increased prices of natural resources and products lead to a focus on specific sectors or goods, weakening other sectors that produce tradable goods that face stronger international competition. When international trade of cash crops even leads to an appreciation of the domestic currency due to large currency inflows, the other sectors may be severely harmed.
} 
2010). These environmental effects may have further negative economic and demographic effects, e.g., by hurting agricultural production of small-scale farmers and inducing internal migration due to environmental stress.

Arguably, the effects described above may increase the risk of ethnic conflict by reducing its opportunity costs. For instance, if LSLA activity reduces economic opportunities for smallscale farmers, conflict becomes a more attractive option to change the economic status quo.

The ethnic dimension of conflict due to LSLA may be further amplified by the question of land ownership. Diergarten and Krieger (2015) argue that the debate about LSLA ultimately boils down to the question of who owns the property rights to use or sell a lot of land. In many less developed countries (e.g., in Africa; see Peters, 2004; Deininger and Castagnini, 2006), traditional land rights defined along ethnicity clash with modern land rights codified into law and enforceable in a court. Thus, land deals may, e.g., get problematic once the seller of land belongs to one ethnic group, while the actual users belong to another ethnicity. For instance, this the case when public land, which is used traditionally by one local ethnic group, is sold to an international investor by the national government, which is dominated by another ethnic group. The resulting grievances may trigger tensions explicitly associated with ethnicity. As another example, national government, assuming that it is dominated by a first ethnic group, may now decide to sell the lot to an international investor, thereby ignoring the tradition of informal local land use by a second ethnic group. Even if the national government did not plan to harm the local population in such a situation, it is very likely that ethnic tensions arise because the second group will perceive the land deal as a negative externality imposed on them by another ethnic group. Depending on the perceived or actual harm, ethnic grievances result that have the potential to cause not only disagreement, but also conflict. This effect is even more aggravated when the first ethnic group actually is able to capture most of the accruing rents from selling the land, while the second group experiences hardly any benefits at all from the deal, only harm (including, e.g., negative environmental externalities). This redistribution of rents increases the probability of ethnic conflict even further. Finally, the land deal may result in a higher level of perceived inequality and relative deprivation if the new investor decides to hire workers from a different ethnicity than the local one (cf. Hunziker and Cederman, 2015).

How LSLA may decrease ethnic conflict risk. Another strand of the literature emphasizes the potential benefits associated with LSLA. These may include: 
- Access to foreign capital, foreign exchange and technology, which foreign investors are usually expected to bring with them. Access to foreign technology may also spill-over to local small-scale farmers, improving local competiveness.

- Increased productivity, which should result from the use of improved (potentially, foreign) technology and further scale-economy effects. Such increases in productivity may also enhance local food security (Robertson and Pinstrup-Andersen, 2010). What is more, when LSLA primarily focus on non-cultivated but suitable land, the gains in food security may be even more pronounced (Deininger and Byerlee, 2012).

- Further macroeconomic gains. Positive externalities from the inflow of foreign capital and technology may accelerate overall economic growth, meaning that the agricultural sector may work as a growth engine. LSLA activity geared towards the use of formerly uncultivated land may similarly boost growth and employment (Robertson and Pinstrup-Andersen, 2010; Deininger and Byerlee, 2012). Land deals that are associated with other commercial uses (e.g., mining, industrial production, tourism) may likewise produce beneficial macroeconomic effects.

- Infrastructure development. For one, there may be contractual obligations associated with specific land deals to update rural infrastructure, build schools and rural health clinics (Robertson and Pinstrup-Andersen, 2010). For another, foreign investors may by themselves decide to develop the local infrastructure (e.g., by road-building) so as to better exploit their newly acquired land. In any event, investment in infrastructure and public services can be expected to produce a number of socio-economic benefits (e.g., better health and education) that also reduce local poverty.

Potentially, the benefits due to LSLA may reduce the risk of ethnic conflict by raising its opportunity costs. For instance, gains in productivity, employment, economic growth or infrastructure may reduce ethnic grievances and make it less likely that ethnic groups affected by LSLA want to challenge the social status quo through conflict.

The role of democratic institutions. As our discussion stands now, more arguments seem to favor the idea that LSLA induce rather than reduce the risk of ethnic conflict. Simple observation, however, suggests that the links between LSLA and conflict may not be that straightforward. That is, there are many countries in the world where conflict does not arise despite LSLA as well as a high level of fractionalization along ethnic lines. Arguably, LSLA ought to have little to no effect on ethnic tensions in these countries. Consistent with the notion that sound institutions may play a role in moderating ethnic conflict (e.g., De Nevers, 1993; 
Bardhan, 1997; Easterly, 2001), we argue that countries may escape ethnic conflict due to LSLA when they exhibit political institutions that can accommodate possibly arising grievances in non-violent ways. With respect to the LSLA-ethnic conflict nexus, democratic institutions may ameliorate ethnic conflict in the following ways:

- Democracies maximize political participation and exhibit systems of checks and balances. For instance, ethnic groups and minorities may have political representation or may even participate in national governments. As another example, local (subnational) governments may have a say in LSLA. Such protective measures ought to make it less likely that large-scale land projects are realized that penalize specific ethnic groups (by "grabbing” their land) and may thus induce conflict. Rather, they should promote LSLA that are actually advantageous to local ethnic groups.

- Democratic systems increase the possibility that the losers of LSLA (e.g., small-scale farmers) are compensated (e.g., via unemployment benefits or resettlement assistance); such compensations may be paid by taxing the winners of LSLA, thus distributing the benefits of LSLA more equally. Arguably, such compensation ought to be in the natural interest of a government that wants to be re-elected.

- Finally, democracies are more likely to uphold the rule of law and protect fundamental civil liberties such as the protection of property rights (Knutsen, 2011). For instance, this is expected to make it less likely that predatory interests simply expulse small-scale landowners from their property or that informal or customary land-use rights are wholeheartedly disregarded.

In sum, these arguments suggest that democratic governments that care for re-election and broad popular appeal ought to ameliorate grievances associated with LSLA; democratic institutions and principles are also likely to protect - to some extent-the losers and less powerful players involved in large-scale land deals. By contrast, non-democratic regimes do not need to care for re-election concerns, thus being less likely to consider the rights of ethnic minorities and traditional local smallholders. Rather, "ethnic” autocracies that rely on specific ethnicities for power may even have incentives to sell land of ethnic groups excluded from power. Here, non-democratic regimes are also expected to use more prevalently non-legal means to carry out LSLA (e.g., via forced evictions), to be more susceptible to "insider" actions (corruption etc.) in the context of LSLA and to be less likely to compensate the losers of LSLA. We shall test whether democratic institutions indeed matter to the nexus between LSLA and ethnic conflict in Section 4. 


\section{Data and Methodology}

To study the effect of large-scale land acquisitions on the risk of ethnic tensions, we compile data on 133 countries for the 2000-2012 period. The summary statistics are reported in Table 1. A list of countries is provided in the appendix.

\section{- Table 1 here-}

\subsection{Dependent Variable: Risk of Ethnic Tensions}

Data on ethnic tensions risk is drawn from the International Country Risk Guide (ICRG, 2014). According to the ICRG (2014), this variable is an expert assessment of the degree of tension within a country attributable to racial, nationality or language divisions; the assessment is repeated annually, so we have time-variant data for the entire period of 2000-2012 available. The variable ranges from 0 to 1 , where higher values are given to countries where racial and nationality tensions are high because, e.g., opposing ethnic groups are intolerant and unwilling to compromise. In line with our discussion in Section 2, we expect these tensions to be also influenced by LSLA.

Figure 2 provides a kernel density estimation-a non-parametric method to estimate the probability density function of our variable of interest, the ethnic risk variable- to give a smooth illustration how the risk of ethnic tensions is distributed for our sample. As illustrated, many countries in our sample either have no (e.g., South Korea and Finland) or only a moderate (e.g., Mali) risk of ethnic tensions (meaning that the average ethnic tension risk variable is $<0.35$ ). However, there are also a number of countries where the risk of ethnic tensions is considerable (i.e., the average ethnic tension risk variable is $>0.5$ ); examples of high-tensions countries include Ethiopia, the Democratic Republic of the Congo, Turkey, Madagascar, Cameroon, Sri Lanka, Sudan, Russia, Pakistan, India and Indonesia.

\section{-Figure 2 here-}

\subsection{Main Explanatory Variable: Land Deals}

Large land acquisitions are measured as the total size of land deal contracts (in hectares) for a specific country-year observation. ${ }^{5}$ The data are drawn from the Land Matrix Dataset (Land

\footnotetext{
${ }^{5}$ As pointed out by a referee, it may be helpful to measure land contract deals not only in absolute but also relative terms. On the one hand, we always control for population size to account for obvious scale effects. On the other hand, as a robustness check, we also use as
} 
Matrix Global Observatory, 2016); the data are produced by a global, independent land monitoring initiative. Generally speaking, a land deal is an intended, concluded or failed attempt to acquire land through purchase, lease or concession.

In our study, we concentrate on concluded (by oral agreement or signed contract) rather than intended or failed land acquisitions, as the latter are less likely to spur ethnic tensions. In the Land Matrix Dataset, a land deal is recorded when the deal (i) entails a transfer of rights to use, control or ownership of land through sale, lease or concession; (ii) must have been initiated since the year 2000; (iii) cover an area of 200 hectares or more; and (iv) imply the potential conversion of land from smallholder production, local community use or important ecosystem service provision to commercial use. Commercial use may be related to, inter alia, agricultural or lumber production, carbon trading, industry or tourism.

\subsection{Further Controls}

A country's risk of ethnic tensions may not only be determined by LSLA activity. Other politico-institutional, economic and demographic factors may matter as well. Therefore, we control for the following factors:

- Democratic accountability; drawn from the ICRG, this variable is an evaluation of the quality of a country's political institutions. Democracies that see free and fair elections, multiple political parties, an independent judiciary and the protection of civil liberties are characterized by high levels of democratic accountability, while one-party states and other authoritarian government types see only low levels of it.

- Bureaucratic quality; also compiled from the ICRG, this variable indicates the quality of a country's economic institutions. A high level of bureaucratic quality coincides with a strong bureaucracy that is somewhat autonomous from political pressure, thus minimizing revisions of policy when governments change (ICRG, 2014).

- Government instability; this variable is an assessment both of the government's ability to carry out its declared program as well as its ability to stay in office. High values of this indicator coincide with a national government with strong legislative and popular support. The data are also drawn from the ICRG.

independent variables the ratio of land contract deal size to a country's total area as well as the ratio of land deal size to a country's total population. The results from the latter robustness checks (available upon request) are in line with the main findings reported in the text. 
- Economic development; it measured as a country's (logged) level of per capita income in 2005 US\$), with the data coming from the World Development Indicators (WDI) (World Bank, 2014).

- Population size; this variable is defined as the (logged) number of inhabitants of a country, i.e., as an indicator of country size. The data are also from the WDI.

- Ethnic fractionalization; this variable is defined as the probability that two random citizens of a given country do not belong to the same ethnic group, the data being drawn from Alesina et al. (2003). Higher values of this variable coincide with a higher level of ethnic diversity. Alesina et al. (2003: 159) make clear that their "definition of ethnicity involves a combination of racial and linguistic characteristics”, so that ethnic fractionalization is a consequence of belonging to different peoples (e.g., tribes in Africa) and/or having different languages (e.g., in Switzerland).

- As part of our robustness checks, we control for religious fractionalization (i.e., the probability that two random citizens of a given country do not belong to the same religious group) and the age-dependency ratio (i.e., the ratio of dependents-those younger than 15 or older than 64-to the working-age population), the former being drawn from Alesina et al. (2003) and the latter coming from the WDI.

The choice of these controls follows the empirical literature on the determinants of ethnic conflict (e.g., Easterly, 2001; Reynal-Querol, 2002: Saideman et al., 2002; Blimes, 2006; Esteban et al., 2012). ${ }^{6}$ First, sound political institutions (democratic accountability) ought to ameliorate ethnic tensions by offering an ethnic minority protection and political voice. Second, sound economic institutions (bureaucratic quality) are similarly expected to reduce the risk of ethnic conflict by facilitating economic participation through markets rather than along ethnic lines. Third, political instability (government instability) is expected to make conflict more likely, e.g., as it constraints the government's ability to accommodate ethnic grievances, while signaling weakness that may invite ethnic opportunism. Fourth, higher levels of economic development (per capita income) should make ethnic tensions less likely by increasing its

\footnotetext{
${ }^{6}$ This literature is mostly concerned with the explanation of civil wars and genocides and the role ethnic factors play in the emergence of these high-scale conflicts. Our measure of ethnic conflict - the risk of ethnic tensions — instead also measures lower-scale ethnic strains (ranging from, e.g., mere political tensions between different ethnic groups to ethnic-communal riots and ethnic terrorism), allowing us to more generally study the effect of LSLA on ethnic tensions and ethnic violence.
} 
opportunity costs; a larger "economic pie" is expected to make ethnically-charged conflict over its distributions less probable. Finally, demographic factors (ethnic and religious fractionalization, population size, age-dependency ratio) should also matter. For instance, larger and more fractionalized populations should facilitate mobilization for ethnic conflict, meaning that there is simply a larger pool of potential recruits and supporters to exploit ethnic divisions. Also, the same demographic conditions may signal the existence of further grievances. For instance, in strongly ethnically fractionalized countries the possibilities for ethnic divisions (e.g., over the distribution of land, wealth and power) should multiply, while a country's economic growth and institutional performance may suffer when ethnic fractionalization becomes too large (Alesina et al., 2003), providing further incentives for conflict. ${ }^{7}$ As for another demographic variable, for instance, an unfavorable age-dependency ratio may induce conflict between different age cohorts that may also be carried out along ethnic lines.

\subsection{Methodology}

Given that the ethnic tensions variable can only take on (continuous) values between 0 and 1, a fractional response (logit) model is most appropriate. This method is described in, e.g., Papke and Wooldridge (1996). For the sake of robustness, we also report findings from Poisson and OLS estimations. Besides the controls discussed above, all specifications include regional and year dummies to account for region- and year-specific effects. ${ }^{8}$ All covariates enter the models in lagged form to reduce endogeneity concerns. ${ }^{9}$ Finally, we always report country-clustered

\footnotetext{
${ }^{7}$ Note that we only argue that fractionalization raises the risk of conflict. We do not argue that ethnic fractionalization (ethnic diversity) has to automatically translate into ethnic conflict. As shown by Fearon and Laitin (1996), interethnic cooperation is indeed a far more common outcome than interethnic conflict due to the latter's costs and the benefits from cooperation.

${ }^{8}$ Regional dummies are included to indicate Western countries (Western Europe, USA and Canada, Japan, Australia and New Zealand), Latin America, Sub-Saharan Africa, post-Soviet countries (e.g., in Eastern Europe) as well as countries in the Middle East and Northern Africa, with the remaining (Asian) countries being the reference group.

${ }^{9}$ As pointed out by a referee, a one-year lag may not be sufficient to fully capture the effect of land deals on ethnic tensions because it may take some time for land deals to be realized (e.g., due to bureaucratic hurdles). As a robustness check, we therefore also consider additional lags (e.g., $t-1$ to $t-4$ ) of the LSLA variable and their joint effect (examined via a series of $F$-tests) on ethnic tension risk; these additional robustness checks (available upon request) support our main findings.
} 
(heteroskedasticity- and autocorrelation-consistent) standard errors to account for data traits (heteroskedasticity and autocorrelation) inherent to panel data.

\section{Empirical Results}

\subsection{Main Results}

Our main empirical results are reported in Table 2. Considering our main independent variable of interest, we find that higher levels of LSLA activity are associated with a higher risk of ethnic tensions. This result is robust to the inclusion of additional controls and the use of alternative estimation methods. Considering our discussion in Section 2, this suggests that the negative consequences from LSLA outweigh its benefits, consequently contributing to the emergence of ethnic tensions. On the one hand, this may be due to increased scarcity and competition over land that accompanies LSLA, creating or deepening ethnic grievances. On the other hand, negative effects of LSLA (e.g., environmental degradation, increased food insecurity, economic insecurity and evictions of small-scale land owners) may also-indirectly-fuel ethnic tensions.

\section{- Table 2 here-}

The (unconditional) effect of LSLA on ethnic tensions is also shown in Figure 3. Here, we hold all other covariates at their respective means (regional- and year-dummies are held at zero), showing that the conditional (expected) mean of ethnic conflict risk rises from 0.34 when there are no LSLA to 0.52 when a country-year observation sees LSLA activity of a size of 2,000,000 hectares (e.g., as Sudan in 2009 and the Democratic Republic of the Congo in 2012). Importantly, the positive (i.e., tension-inducing) and economically substantive effect of LSLA on ethnic tensions also holds when we reduce our country sample to only include countries that experienced noticeable LSLA activity between 2000 and 2012 (meaning that, e.g., all Western countries are dropped from the sample) (results available upon request).

\section{-Figure 3 here-}

Considering the controls, we find that higher levels of per capita income are associated with lower levels of ethnic tensions, potentially as the opportunity costs of ethnic conflict increase with the level of economic development. As expected, larger populations and stronger ethnic fractionalization lead to more ethnic tensions. Presumably, higher values of these covariates coincide with a higher potential for ethnic mobilization; e.g., a larger pool from where to draw recruits for an ethnically motivated conflict. Ethnic tensions are also more likely when a country’s government is instable. This finding is intuitive. For example, when a government 
lacks popular support it may be less likely to accommodate ethnic grievances or suppress ethnic tensions. Finally, we do not find that weak political and economic institutions ${ }^{10}$ are by themselves associated with a greater risk of ethnic tensions.

\subsection{The Role of Democratic Accountability}

Even though our results suggest that weak political institutions do not matter to ethnic tensions per se, they may nevertheless play a role for the LSLA-ethnic tensions nexus as moderating variables. That is, the quality of a country's political institutions may determine if and/or how (positively or negatively) LSLA activity affects ethnic tensions. More precisely, in Section 2 we already discussed that countries in which democratic institutions are sound may be less susceptible to the ill effects of LSLA that may consequently fuel ethnic tensions. For instance, governments that are democratically accountable for their actions need to more strongly consider backlash due to LSLA (e.g., in the form of compensation payments), thus making ethnic tensions due to LSLA less likely.

To study the moderating role of democratic accountability in the LSLA-ethnic tensions nexus, we amend our baseline model with a multiplicative interaction term of democratic accountability and LSLA activity. The associated regression results are reported in specification (4) of Table 2. To give the interaction analysis estimates a straightforward interpretation, we follow Braumoeller (2004) and present a graphical illustration of the interaction effects in Figure 4. Here, all other covariates are held at their respective means (regional- and yeardummies are held at zero), while we vary the level of LSLA activity for a given value of the democratic accountability variable that takes on values from 0 (autocracy) to 0.5 (anocracy) to 1 (full democracy).

\section{-Figure 4 here-}

Figure 4 indicates that the quality of a country's political institutions indeed moderates the relationship between LSLA and the extent of ethnic tensions. While countries with poor political institutions (i.e., with no or little democratic accountability) see higher levels of ethnic tensions as LSLA activity increases, our model predicts fully democratic countries that see LSLA activity (for our sample, e.g., India and Romania) to experience a somewhat lower risk

\footnotetext{
${ }^{10}$ Note that replacing bureaucratic quality with other proxies of the quality of economic institutions (corruption, security of property rights, the rule of law) yields similar result (results available upon request).
} 
of ethnic tensions as this activity grows. In other words, fully democratic countries do not suffer from LSLA in terms of higher ethnic tension risk; there is even evidence that they may profit from it when this activity becomes very large. ${ }^{11}$ More precisely, when democratic accountability is high (between 0.8 and 1), countries have a lower risk of ethnic tensions as LSLA activity increases, while low democratically accountability $(<0.5)$ results in a positive (tension-inducing) association between LSLA and tension risk; for countries with moderate levels of accountability (between 0.5 and 0.8), the interacting effect between LSLA activity and accountability does not matter to ethnic tension risk. Taking Sub-Saharan Africa as an example, many countries in these part of the world are plagued by accountability deficits (e.g., the DR Congo, Côte d'Ivoire, Zimbabwe), while experiencing LSLA activity; for these countries, such a combination is predicted by our model to further fuel ethnic tensions. For other countries in Sub-Saharan Africa that have seen high levels of accountability or have seen sufficiently large accountability improvements in recent years (e.g., Ghana), LSLA activity may have, by contrast, pacifying effects.

In general, our findings speak to our theoretical discussion in Section 2. Potentially, democratic institutions offer a variety of ways to counter or at least minimize the negative consequences potentially associated with LSLA. For instance, these means may include guarantees to personal property and access to an impartial judicial system ${ }^{12}$, which should make expulsions and other forms of predatory behavior by large-scale land investors less likely. At the same time, democracies ought to be more likely to compensate the losers of LSLA activity (e.g., smallscale farmers suffering from increased competition due to LSLA). By contrast, weakly- or nondemocratic countries can be expected to invite predatory investment behavior, while simultaneously disregarding the grievances of ethnic groups or minorities. Thus, it is intuitive to find these latter countries to be much more vulnerable to the risks of ethnic conflict. In general, our finding is in line with, e.g., Bardhan (1997) that sound democratic institutions may offer important moderating mechanisms (e.g., giving political voice to ethnic minorities, reining

\footnotetext{
${ }^{11}$ Note that no country in our sample is strongly democratic (democratic accountability $>0.8$ ) and has LSLA activity that exceeds 750,000 hectares. For strongly democratic countries with only limited LSLA activity, the benefits from LSLA (i.e., a reduced risk of ethnic tensions) are rather small. However, at the same time, these countries are not more likely to see ethnic tensions compared to strongly democratic countries that see no LSLA activity at all.

${ }^{12}$ Indeed, the democratic accountability variable is highly and positively correlated with both property rights protection and the rule of law.
} 
in political dominance of ethnic majorities through checks and balances, fostering trust and commitment between different ethnic groups) to reduce the risk of ethnic tensions.

\section{Conclusion}

Ethnic tensions have serious consequences for affected countries, potentially giving rise to political stalemate, instability and violence, while also reducing domestic economic activity. In this contribution we study how LSLA affect the risk of ethnic tensions. ${ }^{13}$ This research focus is motivated by the recent interest in the determinants and consequences of the "global land rush" and by the strong association between land and ethnicity that is particularly prevalent in less developed countries.

Using data for 133 countries for the 2000-2012 period, we show that more LSLA activity correlates with a higher ethnic tension risk, suggesting that the negative socio-economic and demographic consequences of LSLA activity (e.g., food insecurity, impoverishment of smallscale farmers, forced evictions and migration of traditional land-owners) outweigh its potential benefits, consequently influencing the opportunity costs of ethnic conflict in ways that make ethnic tensions more likely. However, we also show that countries with strongly democratic institutions are able to withstand the fallout of LSLA activity. Weakly democratic or autocratic countries, by contrast, are noticeably more likely to see ethnic tensions as LSLA activity increases. This latter finding is in line with the idea that democratic institutions are important to moderate social ills potentially associated with LSLA. Less developed countries-as the main targets of LSLA — should thus emphasize democratic reforms to be better protected from the economic, environmental and socio-political ills of LSLA.

\footnotetext{
${ }^{13}$ Our study opens up interesting avenues of future research to focus on when studying linkages between LSLA and ethnic tensions, e.g., by accounting for differences in attachment to land of different ethnic groups, different socio-cultural norms across ethnicities and countries regarding land ownership as well as using more refined measurements of ethnicity and ethnic conflict that also emphasizes a sub-national spatial perspective (e.g., concerning the distribution of ethnic groups, land and LSLA activity within countries) more strongly.
} 


\section{References}

Alesina, A., Devleeschauwer, A., Easterly, W., Kurlat, S., Wacziarg, R. (2003). Fractionalization. Journal of Economic Growth 8, 155-194.

Alesina, A., La Ferrara, E. (2005). Ethnic diversity and economic performance. Journal of Economic Literature 43,762-800.

Bardhan, P. (1997). Method in the madness? A political-economy analysis of the ethnic conflicts in less developed countries. World Development 25, 1381-1398.

Blimes, R.J. (2006). The indirect effect of ethnic heterogeneity on the likelihood of civil war onset. Journal of Conflict Resolution 50, 536-547.

Bob, U. (2010). Land-related conflicts in Sub-Saharan Africa. African Journal of Conflict Resolution 10, 49-64.

Braumoeller, B.F. (2004). Hypothesis testing and multiplicative interaction terms. International Organization 58, 807-820.

Bujko, M., C. Fischer, T. Krieger and D. Meierrieks (forthcoming). How institutions shape land deals: The role of corruption. Homo Oeconomicus.

Collier, P., Hoeffler, A. (1998). On the economic causes of civil war. Oxford Economic Papers 50, 563-573.

Corden W.M., Neary, J.P. (1982). Booming Sector and De-Industrialisation in a Small Open Economy. The Economic Journal 92, 825-848.

Cotula, L. (2011): Land deals in Africa: What is in the contracts? London: IIED.

Davis, K.F., D’Odorico, P., Rulli, M.C. (2014). Land grabbing: A preliminary quantification of economic impacts on rural livelihoods. Population and Environment 36, 180-192.

Deininger, K., Byerlee, D. (2011). Rising global interest in farmland: Can it yield sustainable and equitable benefits? Washington, D.C: The World Bank.

Deininger, K., Byerlee, D. (2012). The rise of large farms in land abundant countries: Do they have a future? World Development 40, 701-714.

Deininger, K., Castagnini, R. (2006). Incidence and impact of land conflict in Uganda. Journal of Economic Behavior and Organization 60, 321-345.

De Nevers, R. (1993). Democratization and ethnic conflict. Survival 35, 31-48. 
Diergarten, Y., Krieger, T. (2015). Large-scale land acquisitions, commitment problems and international law. Law and Development Review 8, 217-233.

Easterly, W. (2001). Can institutions resolve ethnic conflict? Economic Development and Cultural Change 49, 687-706.

Easterly, W., Levine, R. (1997). Africa’s growth tragedy: Policies and ethnic divisions. Quarterly Journal of Economics 112, 1203-1250.

Esteban, J., Ray, D. (2011). A model of ethnic conflict. Journal of the European Economic Assocation 9, 496-521.

Esteban, J., Mayoral, L., Ray, D. (2012). Ethnicity and conflict: An empirical study. American Economic Review 102, 1310-1342.

Fearon, J.D., Latin, D.D. (1996). Explaining interethnic cooperation. American Political Science Review 90, 715-735.

Feldman, S., Geisler, C. (2012). Land expropriation and displacement in Bangladesh. Journal of Peasant Studies 39, 971-993.

Hunziker, P., Cederman, L.E. (2015). No extraction without representation: Oil, state intrusion, and ethnic civil war. Mimeo.

ICRG (2014). International Country Risk Guide. Syracuse, N.Y.: The PRS Group, Inc.

Knutsen, C.H. (2011). Democracy, dictatorship and protection of property rights. Journal of Development Studies 47, 164-182.

Land Matrix Global Observatory (2016). Land Matrix Dataset. International Land Coalition (ILC), Centre de Coopération Internationale en Recherche Agronomique pour le Développement (CIRAD), Centre for Development and Environment (CDE), German Institute of Global and Area Studies (GIGA) and Deutsche Gesellschaft für Internationale Zusammenarbeit (GIZ).

Papke, L.E., Wooldridge, J.M. (1996): Econometric methods for fractional response variables with an application to 401(k) plan participation rates. Journal of Applied Econometrics $11,619-632$.

Peters, P.E. (2004). Inequality and social conflict over land in Africa. Journal of Agrarian Change 4, 269-314. 
Reynal-Querol, M. (2002). Ethnicity, political systems, and civil wars. Journal of Conflict Resolution 46, 29-54.

Robertson, B., Pinstrup-Andersen, P. (2010). Global land acquisition: Neo-colonialism or development opportunity? Food Security 2, 271-283.

Saideman, S.M., Lanoue, D.J., Campenni, M., Stanton, S. (2002). Democratization, political institutions, and ethnic conflict: A pooled time-series analysis, 1985-1998. Comparative Political Studies 35, 103-129.

Williams, R.M. (1994). The sociology of ethnic conflicts: Comparative international perspectives. Annual Review of Sociology 20, 49-69.

World Bank (2014). World Development Indicators. Washington, D.C.: The World Bank. 


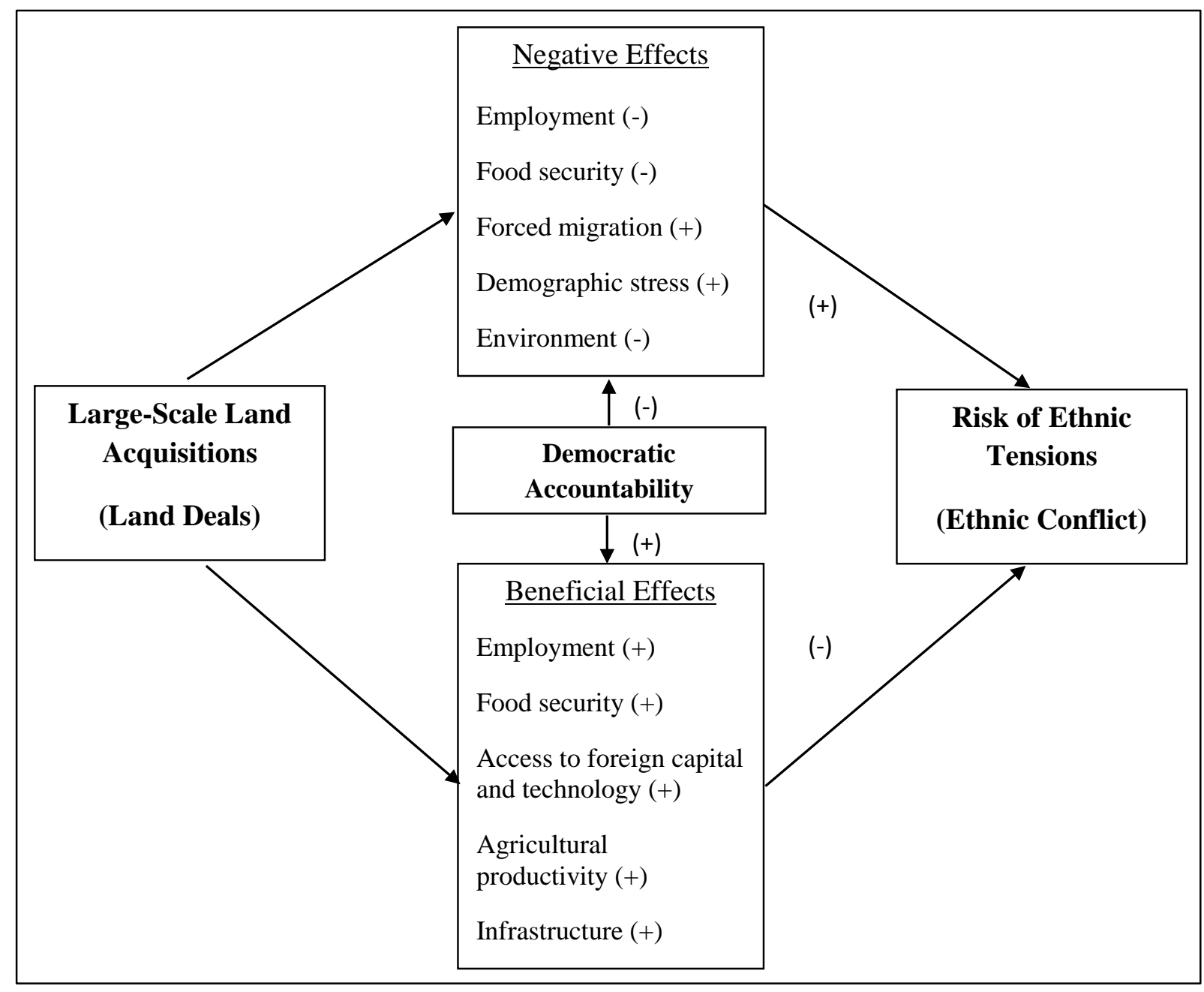

Figure 1: Land Deals and Ethnic Tensions 


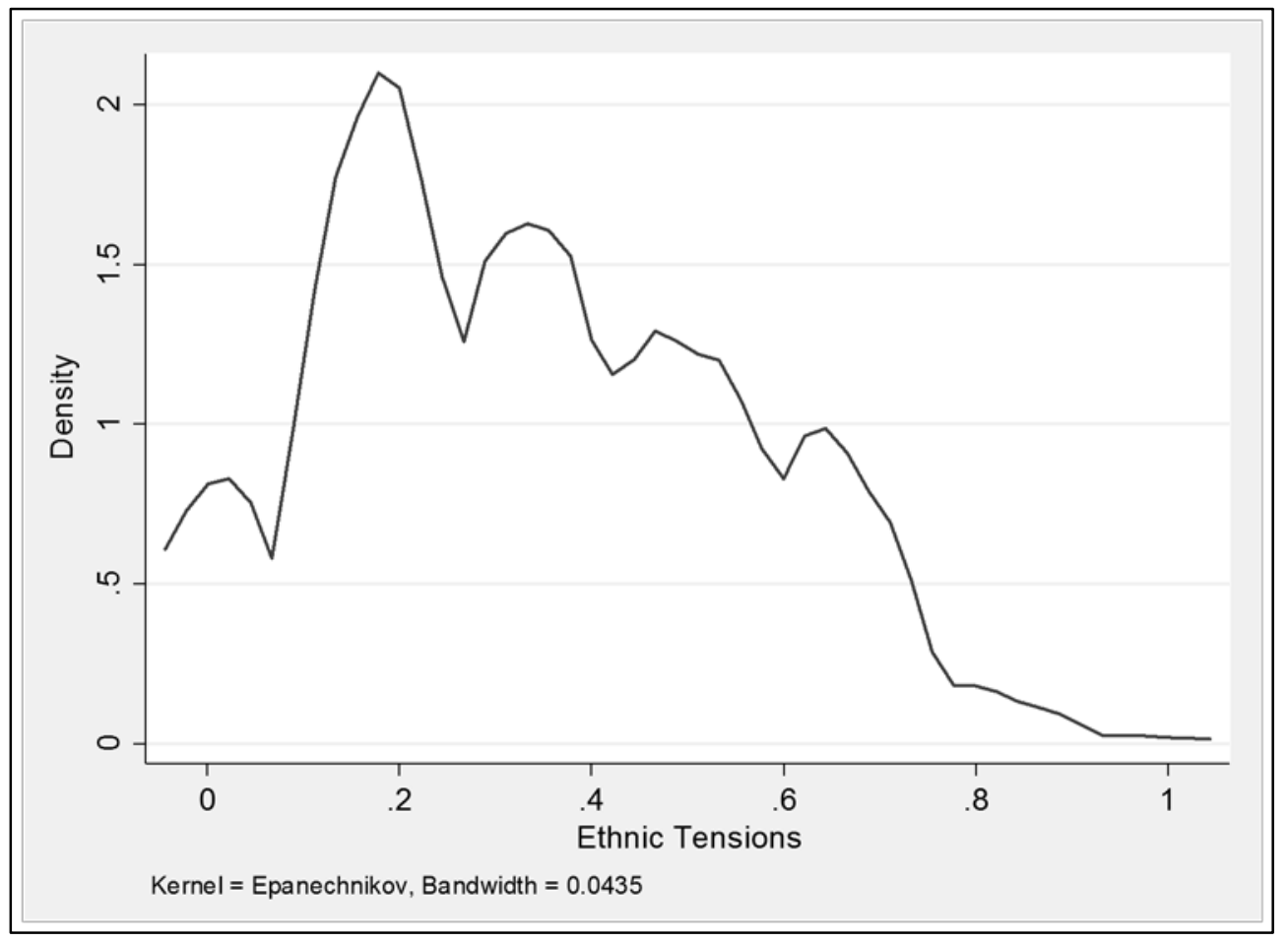

Figure 2: Kernel Density Estimation for Ethnic Tensions

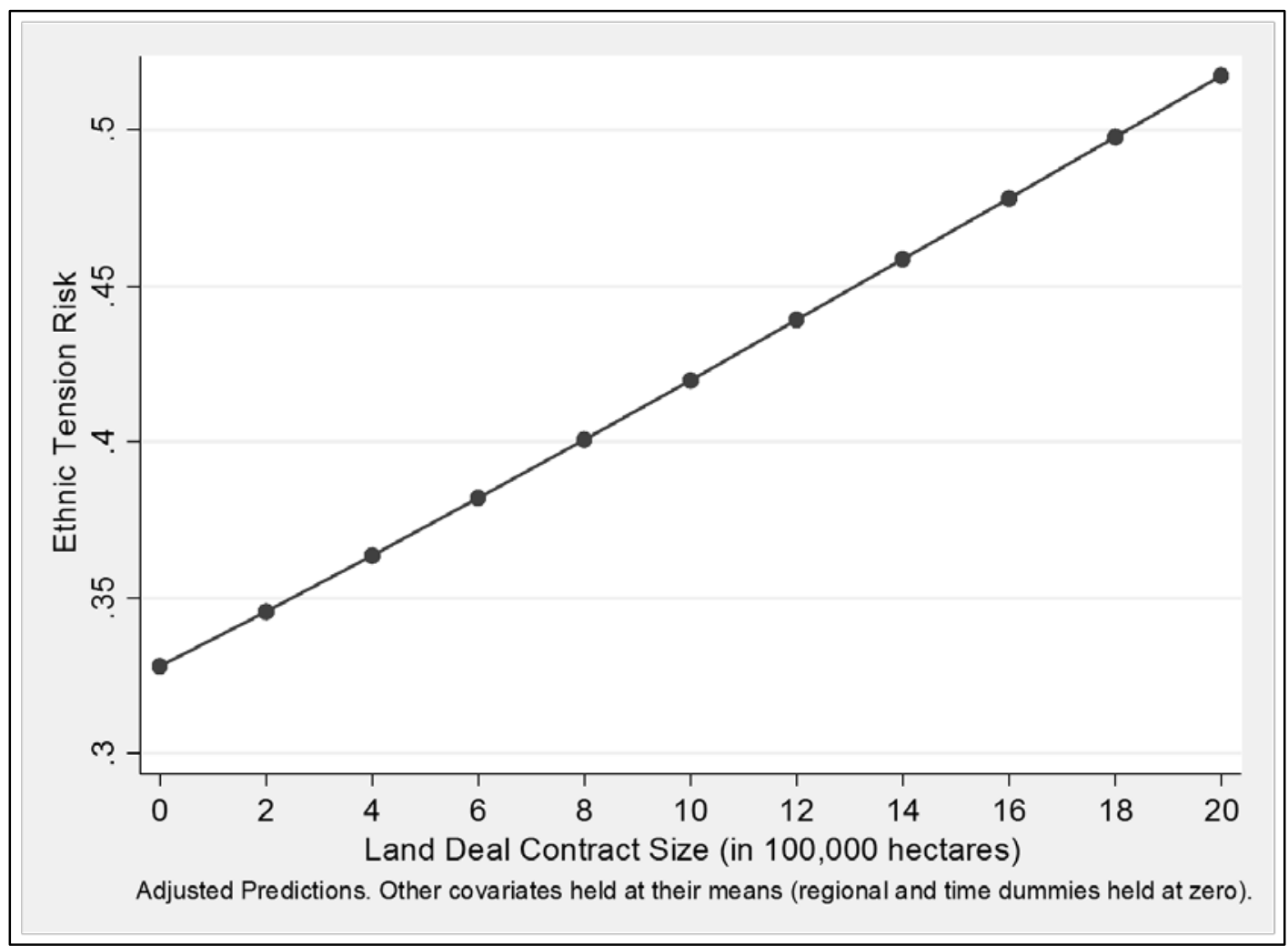

Figure 3: Effect of Land Deals on Ethnic Tensions 


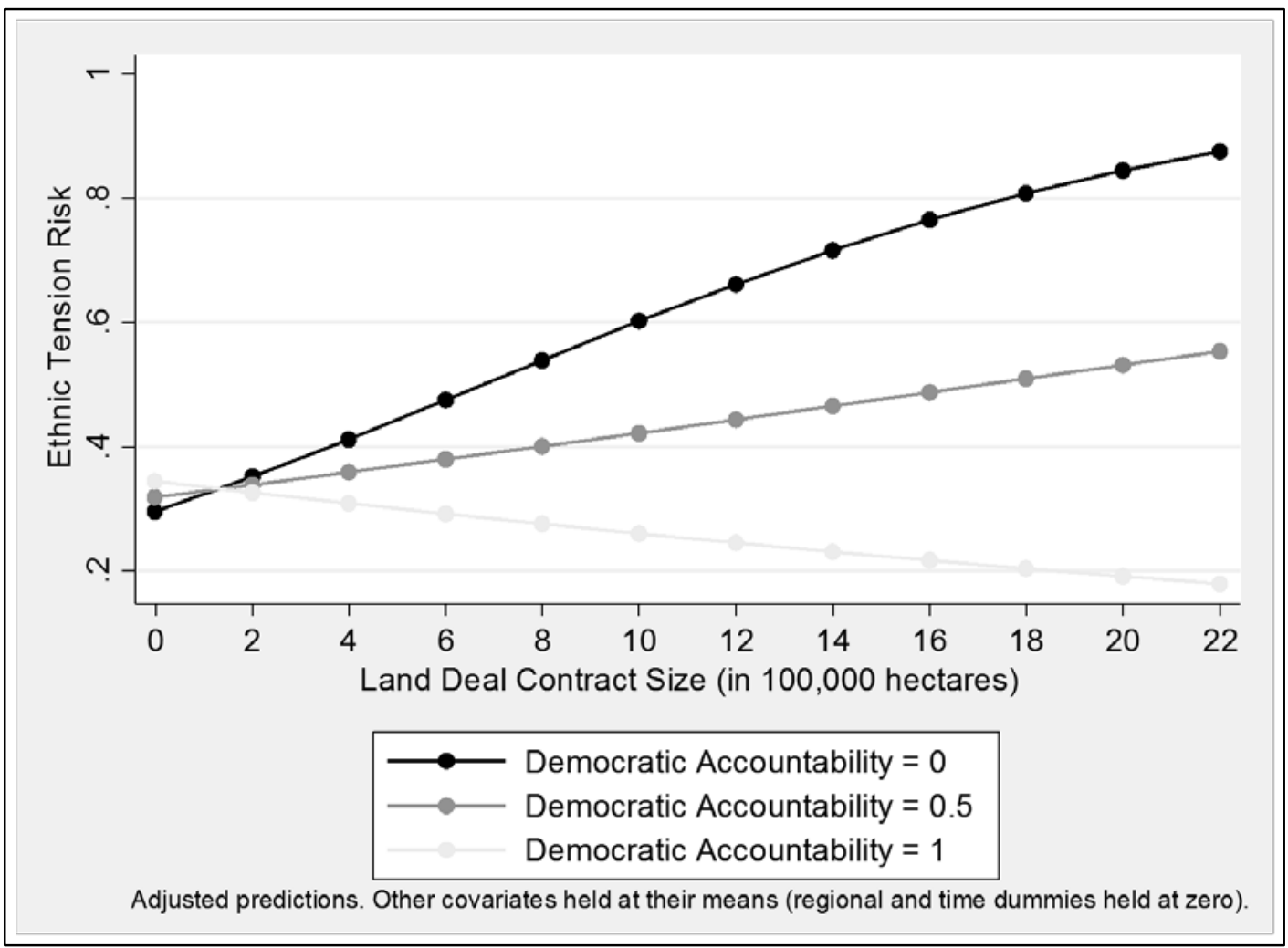

Figure 4: Interaction between Land Deals and Democratic Accountability and the Risk of Ethnic Tensions 


\begin{tabular}{|c|c|c|c|c|c|}
\hline Variable & Observations & Mean & $\begin{array}{l}\text { Standard } \\
\text { Deviation }\end{array}$ & Min & Max \\
\hline Ethnic Tension Risk & 1,729 & 0.339 & 0.215 & 0 & 1 \\
\hline Land Deal Contract Size & 1,729 & 0.182 & 1.210 & 0 & 22.810 \\
\hline Democratic Accountability & 1,729 & 0.670 & 0.281 & 0 & 1 \\
\hline Quality of Bureaucracy & 1,729 & 0.538 & 0.281 & 0 & 1 \\
\hline Government Instability & 1,729 & 0.286 & 0.130 & 0 & 0.736 \\
\hline $\ln$ (GDP per Capita) & 1,672 & 9.164 & 1.269 & 6.089 & 11.804 \\
\hline $\ln$ (Population Size) & 1,729 & 16.349 & 1.516 & 12.547 & 21.024 \\
\hline Ethnic Fractionalization & 1,716 & 0.455 & 0.259 & 0.002 & 0.930 \\
\hline Age Dependency Ratio & 1,729 & 49.336 & 23.872 & 15.496 & 105.461 \\
\hline Religious Fractionalization & 1,729 & 0.431 & 0.237 & 0.002 & 0.860 \\
\hline
\end{tabular}

Table 1: Summary Statistics 


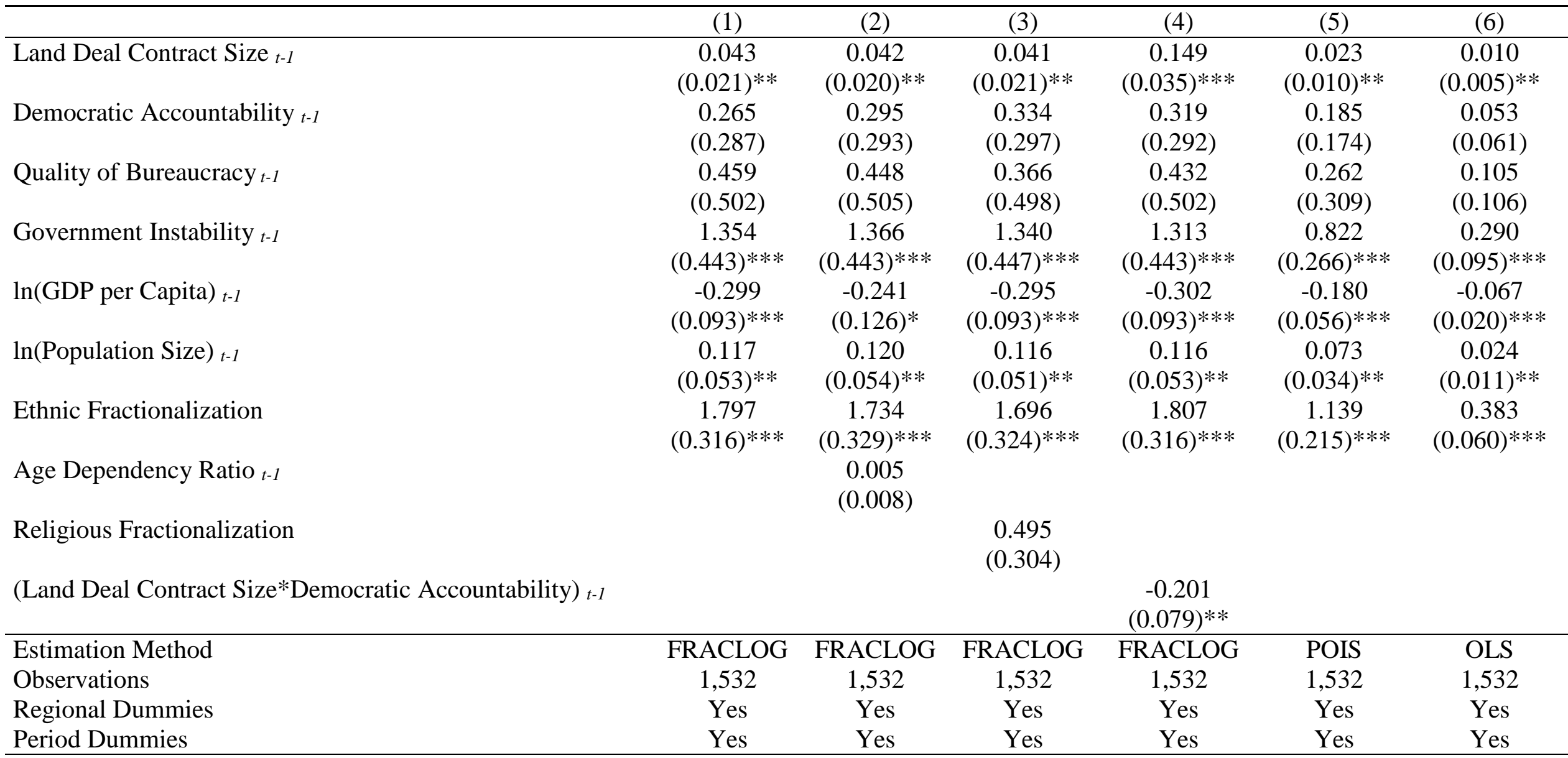

Notes: Constant not reported. FRACLOG $=$ Fractional logistic regression. POIS $=$ Poisson regression. OLS = Ordinary least squares regression. Standard errors clustered over countries in parentheses. $* * * \mathrm{p}<0.01, * * \mathrm{p}<0.05, * \mathrm{p}<0.1$

\section{Table 2: Land Deals and Ethnic Tensions}




\section{Appendix. List of Countries}

Albania, Algeria, Angola, Argentina, Armenia, Australia, Austria, Azerbaijan, Bahrain, Bangladesh, Belarus, Belgium, Bolivia, Botswana, Brazil, Bulgaria, Burkina Faso, Cameroon, Canada, Chile, China, Colombia, Congo (Dem. Rep.), Congo (Rep.), Costa Rica, Côte d'Ivoire, Croatia, Cuba, Cyprus, Czech Republic, Denmark, Dominican Republic, Ecuador, Egypt, El Salvador, Estonia, Ethiopia, Finland, France, Gabon, Gambia, Germany, Ghana, Greece, Guatemala, Guinea, Guinea-Bissau, Guyana, Haiti, Honduras, Hungary, Iceland, India, Indonesia, Iran, Iraq, Ireland, Israel, Italy, Jamaica, Japan, Jordan, Kazakhstan, Kenya, Korea (South), Kuwait, Latvia, Lebanon, Liberia, Libya, Lithuania, Luxembourg, Madagascar, Malawi, Malaysia, Mali, Mexico, Moldova, Mongolia, Morocco, Mozambique, Myanmar, Namibia, Netherlands, New Zealand, Nicaragua, Niger, Nigeria, Norway, Oman, Pakistan, Panama, Papua New Guinea, Paraguay, Peru, Philippines, Poland, Portugal, Qatar, Romania, Russia, Saudi Arabia, Senegal, Sierra Leone, Singapore, Slovak Republic, Slovenia, Somalia, South Africa, Spain, Sri Lanka, Sudan, Suriname, Sweden, Switzerland, Syria, Tanzania, Thailand, Togo, Trinidad and Tobago, Tunisia, Turkey, Uganda, Ukraine, United Arab Emirates, United Kingdom, United States, Uruguay, Venezuela, Vietnam, Yemen, Zambia, Zimbabwe. 